\title{
PENINGKATAN KEMAMPUAN GURU DALAM PENGELOLAAN PBM MELALUI PELAKSANAAN SUPERVISI AKADEMIK DENGAN PENDEKATAN KOLABORATIF DI SMP N I UJUNGBATU SEMESTER 1 TAHUN PELAJARAN 2016/2017
}

\author{
AUSYKARNI \\ Guru SMPN 1 Ujungbatu
}

\begin{abstract}
ABSTRAK
Penelitian ini bertujuan mengetahui pelaksanaan dan peningkatan kemampuan guru dalam pengelolaan PBM melalui pelaksanaan supervisi akademik dengan pendekatan kolaboratif di SMPN I Ujungbatu Semester 1 Tahun Pelajaran 2016/2017 khususnya pada aspek pengelolaan kegiatan belajar mengajar. Jenis penelitian ini adalah penelitian tindakan sekolah. Metode dan rancangan penelitian tindakan sekolah ini dilakukan dengan prosedur penelitian berdasarkan pada prinsip Kemmis dan Taggart (1988:10) yang mencakup kegiatan sebagai berikut : (1) perencanaan (planning), (2) pelaksanaan tindakan (action), 3) observasi (observation), (4) refleksi (reflection). Subjek penelitian adalah guru di SMPN I Ujungbatu pada Semester 1 Tahun Pelajaran 2016/2017 sebanyak 8 guru. Teknik pengumpulan data menggunakan observasi, dan studi dokumentasi. Keabsahan data menggunakan triangulasi, yaitu Triangulasi yang digunakan dalam penelitian adalah triangulasi sumber data dan triangulasi metode. Analisis data menggunakan analisis kualitatif. Hasil penelitian menunjukkan peningkatan kemampuan guru dalam pengelolaan proses belajar mengajar (PBM), di mana pada kondisi awal tidak ada guru yang mampu menyusun pengelolaan proses belajar mengajar (PBM) dengan baik hal tersebut dibuktikan dengan rendahnya hasil nilai rata-rata yang diperoleh guru-guru yaitu 49,50 dan hanya masuk dalam kategori KURANG, pada siklus I meningkat cukup signifikan dan terdapat 3 guru atau $37,50 \%$ yang dinyatakan mampu mengelola proses belajar mengajar (PBM) dengan baik, dengan peroleh nilai rata-rata secara klasikal sebesar 66,83 dan masuk dalam kriteria CUKUP dan pada siklus terakhir menjadi guru atau 100\%, dibuktikan dengan perolehan nilai secara klasikal sebesar 80,17 dalam kriteria nilai BAIK. Dari hasil penelitian sebagaimana dijelaskan di atas dapat disimpulkan bahwa pelaksanaan supervisi akademik dengan pendekatan kolaboratif di SMPN I Ujungbatu Semester 1 Tahun Pelajaran 2016/2017 terbukti dapat meningkatkan kemampuan guru dalam pengelolaan PBM.
\end{abstract}

Kata Kunci : supervisi akademik, kolaboratif, kemampuan, PBM

\section{PENDAHULUAN \\ Latar Belakang Masalah}

Pembelajaran adalah suatu aktivitas belajar-mengajar. Di dalamnya ada dua subjek yaitu guru dan peserta didik. Tugas dan tanggung jawab utama seorang guru adalah mengelola pembelajaran dengan lebih efektif, dinamis, efisien, dan positif yang ditandai dengan adanya kesadaran dan keterlibatan aktif diantara dua subjek pembelajaran yaitu guru sebagai penginisiatif awal dan pengarah serta pembimbing, sedangkan peserta didik sebagai yang mengalami dan terlibat aktif untuk memperoleh perubahan diri dalam pengajaran. Pengajaran merupakan aktivitas yang sistematis dan sistemik yang terdiri atas banyak komponen. Masing-masing komponen pengajaran tidak bersifat terpisah atau berjalan sendiri-sendiri, tetapi harus berjalan teratur, saling bergantung, komplementer, dan kesinambungan. Untuk itu diperlukan pengelolaan pembelajaran yang baik. Pengelolaan pembelajaran yang baik harus dikembangkan berdasarkan pada prinsip-prinsip pengajaran. Ia harus mempertimbangkan segi dan strategi pengajaran, dirancang secara sistematis, bersifat konseptual tetapi praktis relistik dan fleksibel, baik yang menyangkut masalah interaksi pengajaran, pengelolaan kelas, pengajaran, maupun penilaian pengajaran.

Dalam kegiatan belajar mengajar sangat diperlukannya interaksi antara guru dan murid yang memiliki tujuan. Agar tujuan ini dapat tercapai sesuai dengan target dari guru itu sendiri, maka sangatlah perlu terjadi interaksi positif yang terjadi antara guru dan murid. Adapun materi yang akan kami bahas dalam makalah pengelolaan pembelajaran yakni pengertian dan hakikat pengelolaan pembelajaran serta pendekatan belajarmengajar.Untuk melaksanakan tugas dalam meningkatkan mutu pendidikan maka diadakan proses belajar mengajar, guru merupakan figur sentral, di tangan gurulah terletak kemungkinan berhasil atau tidaknya pencapaian tujuan belajar mengajar disekolah. Oleh karena itu tugas dan peran guru bukan saja mendidik, mengajar dan melatih tapi juga bagaimana guru dapat mebaca 
situasi kelas dan kondisi siswanya dalam menerima pelajaran.

Untuk meningkatkan peran guru dalam proses belajar mengajar dan hasil belajar siswa, maka guru diharapkan mampu menciptakan lingkungan belajar yang efektif dan mampu mengelola kelas dengan baik. Adapun tujuan yang diniatkan dalam setiap kegiatan belajar mengajar, baik yang sifaatnya instruksional maupun tujuan peniring akan dapat dicapai secara optimal apabila dapat menciptakan dan mempertahankan kondisi yang menguntungka bagi peserta didik. Dalam setiap proses pembelakjaran kondisi inni harus direncanakan dan diusahakan oleh guru secara sengaja agar dapat terhindar dari kondisi yang merugikan. Dan kembali kepada kondisi yang optimal apabila terjadi hal-hal yang merusak yang disebabkan oleh tingkah laku peserta didik didalam kelas.

Usaha guru dalam menciptakan kondisi yang diharapkan akan efektif apabila : Pertama, diketahui secara tepat faktor-faktor yang dapat menunjang terciptanya kondisi yang menguntungkan dalam proses belajar mengajar. kedua, dikenal masalah-masalah yang diperkirakan dan biasanya timbul dan dapat merusak iklim belajar mengajar. Ketiga, dikuasainya berbagai pendekatan dalam pengelolaan kelas dan diketahui pula kapan dan untuk masalah mana suatu pendekatan digunakan (Ahmad Rohani, 2004:122). Suatu kondisi belajar optimal dapat tercapai jika guru mampu mengatur siswa dan sarana pengajaran serta mengendalikannya dalam suasana yang menyenangkan dalam mencapai tujuan pengajaran.

Dalam pengelolaan proses pembelajaran mengajar di SMPN001 Ujung Batu. yang dilaksanakan oleh para guru masih bersifat konvensional, yaitu metode pembelajaran yang monoton yang diajarkan oleh guru serta keterbatasan sarana dan prasarana sekolah. Dari gambaran tersebut sangatlah jelas bahwa proses pembelajaran yang dilaksanakan menjadi kurang maksimal. Keberhasilan dalam kegiatan belajar mengajar merupakan tujuan yang paling diharapkan oleh semua guru. Untuk itu guru harus mampu menciptakan situsi belajar yang efektif. Karena suatu proses belajar mengajar yang efektif berlangsung apabila memberikan keberhasilan serta memberikan rasa puas bagi siswa maupun guru. Seorang guru merasa puas jika siswanya dapat mengikuti proses pembelajaran dengan sungguh-sungguh, bersemangat dan penuh kesadaran tinggi. Hal itu dapat tercapai apabila guru memiliki sikap dan kemampuan secara profesional serta mempunyai kemampuan mengelola proses belajar mengajar yang menyenangkan dan efektif.

Dari hasil pelaksanaan kegiatan awal penelitian menunjukkan bahwa semua guru masih kurang maksimal dalam pengelolaan pembelajaran di kelasnya masing-masing. Hasil penilaian pada kegiatan supervisi awal menunjukkan bahwa tidak ada guru yang memenuhi indikator penilaian minimal dalam rentang 70-89 atau dalam kriteria baik. Salah satu upaya yang dilakukan oleh peneliti sebagai pengawas sekolah di SMPN 001 Ujung Batu. adalah dengan melaksanakan kegiatan supervisi akademik melalui pendekatan kolaburatif sebagai upaya meningkatkan kemampuan guru dalam pengelolaan proses belajar mengajar.

Menurut Makawimbang dalam Asf dan Mustafa (2013:91), dalam praktik supervisi pendidikan, dikenal bebarapa model supervisi yang selama ini dengan sadar atau tidak sadar dipelaksanaankan oleh supervisor dalam pelaksanaan tugasnya. Setiap model memiliki karakteristik atau kelebihan dan kekurangannya. Oleh karena itu, memahami model-model supervisi memiliki banyak keuntungan tersendiri bagi siapapun yang berprofesi sebagai supervisor pendidikan. Model supervisi yang selama ini diterapkan dalam satuan pendidikan menurut Sahertian (2010:34) adalah supervisi model konvensional (tradisional), model supervisi artistik, model supervisi ilmiah, dan model supervisi akademik. Dalam model supervisi konvensional (tradisional), seorang supervisor dipahami sebagai orang yang memiliki power untuk menentukan nasib guru. Karenanya, dalam perspektif behavior, seorang yang menerapkan model ini selalu menerapkan prilaku atau aksi supervisi dalam bentuk inspeksi dan mencari kesalahan dan menemukan kesalahan bahkan bisa sering kali memata-matai objek, yaitu guru. Model supervisi artistik berdasarkan diri pada bekerja untuk orang lain (working forothers), dan 
bekerja melalui orang lain (working with the others), dan bekerja melalui orang lain (working through the others). Supervisi model ilmiah memiliki ciri-ciri yaitu dilaksanakan secara bersama dan kontinue, sistematis dengan menggunakan prosedur serta teknik tertentu, menggunakan instrumen pengumpulan data, ada data yang objektif yang diperolah dari data yang riil. Supervisi model akademik difokuskan pada peningkatan proses pembelajaran dengan menggunakan siklus yang sistematis. Supervisi akademik membantu guru-guru memperkecil kesenjangan antara tingkah laku mengajar yang nyata dengan tingkah laku mengajar yang ideal.

Pendekatan yang digunakan dalam menerapkan supervisi pendidikan sering didasarkan pada prinsip-prinsip psikologis. Secara teoritis Asf (2013:68), terdapat beberapa pendekatan yang dapat digunakan supervisor dalam melakukan supervisi pendidikan yaitu : pendekatan langsung (direct approach), pendekatan tidak langsung (non-direct approach), dan pendekatan kolaboratif (colaborativeapproach). Dalam pendekatan langsung, supervisor memberikan arahan secara langsung kepada guru- guru yang disupervisi sehingga prilaku supervisor lebih dominan. Pendekatan tidak langsung cara pendekatan terhadap permasalahan yang sifatnya tidak langsung. Di sini supervisor memberikan kesempatan yang sebanyak mungkin kepada para guru untuk mengemukakan permasalahan yang mereka alami.

Pendekatan kolaboratif adalah cara pendekatan yang memadukan cara pendekatan direktif dan non-direktif menjadi suatu cara pendekatanbaru. Pada pendekatan ini, baik supervisor maupun guru bersamasamabersepakat untuk menetapkan struktur proses dan kriteria dalam melaksanakan proses percakapan terhadap masalah yang dihadapi guru. Pendekatan ini didasarkan pada psikologi kognitif. Psikologi kognitif beranggapan bahwa belajar adalah perpaduan antara kegiatan individu dengan lingkungan yang pada gilirannya akan berpengaruh dalam pembentukan aktivitas individu. Dengan demikian, pendekatan dalam supervisi berhubungan pada dua arah: dari atas ke bawah dan dari bawah ke atas.

\section{Pendekatan Kolaboratif}

\section{KAJIAN PUSTAKA}

Jika diperhatikan secara seksama, pendekatan kolaboratif adalah perpaduan antara pendekatan Supervisi direktif dan non direktif. Dugaan itu benar, jika diperhatikan dari aspek tanggung jawab terlaksananya kegiatan Supervisi. Artinya supervisor dan guru berbagi tanggung jawab. Tugas Supervisi dalam hal ini adalah mendengarkan dan memperhatikan secara cermat keluhan guru terhadap masalah perbaikan, peningkatan dan pengembangan pengajarannya, dan sekaligus memperhatikan pula gagasan-gagasan guru untuk mengatasi masalah itu selanjutnya. Supervisor dapat meminta penjelasan terhadap hal-hal yang diungkapkan guru yang kurang dipahami. Selanjutnya ia mendorong guru mengaktualisasikan inisiatif yang dipikirkan untuk memecahkan masalah yang dihadapinya, atau untuk meningkatkan dan mengembangkan pengajarannya (Glickman; Gordon \& Glickman, 1984).

Beberapa pakar Supervisi mengemukakan, bahwa gagasan pendekatan kolaboratif dalam Supervisi, diilhami oleh gerakan hubungan instansi (The Human Relations Movement). Gagasan ini sekaligus merupakan pula reaksi terhadap praktk model Supervisi klasik yang mengatakan bahwa fungsi Supervisi pengajaran adalan untuk mengawasi mutu dengan cara mengarahkan, menunjukkan, mengaharuskan, memantau menilai dan mengajar (Wiles \& Lovell, 1975). Dalam praktek Supervisi, pendekatan ini disebut juga sebagai Supervisi kolegiat, kesejawatan atau korepatif, yang lebih banyak meilhami karya para pakar Supervisi klinis (Lovell dan Wiles, 1983: Cagon 1973, 1976 Goldhammer, 1980).

Krajewski dan Anderson (1980) melalui berbagai penelitian mengembangkan siklus Supervisi yang berbasis hubungan kolaboratif antara Supervisi dan guru untuk mengaktifkan yang berbasis hubungan kolaboratif antara supervisor dan guru untuk mengaktifkan Supervisi. Untuk itu Flanders (1976) menyebut Supervisi kolaboratif sebagai Supervisi klinis selanjutnya, ia menjelaskan bahwa Supervisi kolaboratif merupakan kemitraan dalam inkuiri dua orang yang mengadu alternative, dimana supervisor berposisi semangat mitra yang lebih 
berpengalaman untuk proses inkuri. Lerch (1980) dan Werner (1980) menemukan adanya harapan guru untuk berbagai tanggung jawab dalam proses Supervisi, terutama dalam memecahkan masalah pengajaran yang dihadapi guru. Kedua ahli itu menyimpulkan bahwa pendekatan kolaboratif dalam Supervisi lebih efektif, karena adanya kolgialitas antara supervisor dan guru dalam memecahkan masalah pengajaran yang dihadapi para guru. Kesimpulan itu memperkuat pendapat Sergiovanni (1976) yang menyatakan bahwa hubungan yang lebih intensif dan bersifat kolegial dipersyaratkan dalam Supervisi tradiosional. Reavis (1978) dan Thompson (1979) menemukan fakta bahwa Supervisi harus didasarkan pada kepedulian guru, dan bukan pada kepedulian supervisor. Karena itu guru harus dilatih untuk menetapkan keutusan secara bebas guna mengembangkan sikap profesionalnya, sehingga terwujud apa yang mereka namakan Peer Supervision, Hall (1974) melaporkan ditemukan sikap yang lebih posistif pada para guru yang disupervisi dengan pendekatan kolaboratof. Sementara itu, Shuma (1973) menemukan dalam penelitiannya bahwa para guru yang memperoleh perlakukan berdasarkan Supervisi kolaboratif memiliki perasaan pertumbuhan sebagai gutu. Pertumbuhan itu ditandai dengan adanya hubungan yang dibangun antara supervisor dan guru, jika dibandingkan dengan guru yang tidak pengalami perlakuan semacam itu.

Penelitian yang diadakan oleh Ginkel (1983) terhadap sejumlah guru SD, menempatkan pendekatan kolaboratif pada peringkat pertama, disamping kedua pendekatan Supervisi lainnya. Para guru yang menyatakan bahwa pendekatan Supervisi kolaboratif adalah pendekatan yang paling di sukai. Sementara itu pula, Glickman (1985) dengan menunjuk penelitian yang dilakukan oleh Venezky, Humphries bersama Marsh, menemukan juga katagori pendekatan Supervisi berdasarkan pengalaman mengajar guru. Ia menyimpulkan, guru yang telah berhasil mengembangkan kompetensi dan motivasinya cenderung untuk lebih menyukai pendekatan Supervisi kolabotratif.

Dari kajian di atas timbul pertanyyan: apakah yang membedakan pendekatan
Supervisi pengembangan seperti yang dijelaskan oleh ketiga pendekatan yang telah dikemukakan di atas? Klarifikasi yang dikemukakan oleh Olivia (1984:514) berikut ini, menjelaskan hal tersebut. Carl D. Glickman :has introduced a collaborative orientation between directive and nondirective behavior Glickaman desrribed a supervisory continuum from directive to collaborative to nondirective be orientation for each of thes dominant behavior Glickman outlined a pattern of behaviors, as follows.

Directive

Collaborative

Nondirective

Orientation

Orientation

Clarifying

Listening

Presenting

Clarifying

Demonstrating

Presentating

Directing

Solving

Standardizing

Reinforcing

Initiated

Problem

Presentating

Negotiating

Supervisor

Teacher

Initiated

Dengan demikian, pendekatan Supervisi pengembangan tidak melihat masing-masing pendekatan (Ditektif, kolaboratif, dan non direktif sebagai pendekatan yang berdiri atau terpilah-pilah, melainkan pendekatan ini merupakan suatu kebulatan yang berada dalam suatu kontinum). Jadi proses supervisinya berkembang dari direktif ke kolaboratif, sehingga mencapai tingkat non direktif. Sebagaimana dampak perkembangan dari perolehan belajar guru, (Rossiconne, 1985 : 16) merumuskan sebagai berikut "Development supervision in the process of supervisory behavior that is manifested in recognizing individual teacher's needs, acknowledging and accepting the existence of varied rates of forofessional growth, and consequently, Matching types of supervisory behavior to these need and stages of professional growth".

Penelitian yang dilakukan oleh Glickman (1985), menunjukkan bahwa pengalaman mengajar guru memiliki perananpenting dalam menetapkan pilihan pendekatan Supervisi. Para guru yang memotivasi dan keterampilannya rendah menilai kecenderungan untuk disupervisi dengan pendekatan direktif. Mereka 
yang telah berhasil mengembangkan kompetensi dan motivasinya cenderung lebih menyukai pendekatan kolaboratif. Selanjutnya para guru yang telah memiliki latar belakang pengalaman luas dan kompetensi serta motivasinya tinggi, maupun bekerja sama atau bekerja sendiri, dan mampu menemukan cara mendorong siswa belajar mendiri. Pendekatan yang sesuai bagi para guru yang tersebut terakhir ini adalah pendekatan non direktif.

Sintak pelaksanaan kegiatan supervisi dengan pendekatan kolaboratif sebagaimana dijelaskan tabel di bawah ini.

Tabel 2.1 Sintak Pelaksanaan Kegiatan Supervisi dengan Pendekatan Kolaboratif

\begin{tabular}{|l|l|}
\hline a. Percakapan Awal & $\begin{array}{l}\text { Supervisor bertemu dengan guru atau sebaliknya. Mereka } \\
\text { membicarakan masalah yang dihadapi guru }\end{array}$ \\
\hline b. Observasi & $\begin{array}{l}\text { Dalam observasi digunakan alat pencatatan data. } \\
\text { Dalam percakapan awal supervisor berjanji akan } \\
\text { mengobservasi kelas atau sebaliknya guru mengundang } \\
\text { supervisi untuk mengadakan observasi di kelas. }\end{array}$ \\
\hline $\begin{array}{l}\text { c. Analisis/Interpretasi } \\
\text { d. Percakapan akhir } \\
\text { (past conference) }\end{array}$ & $\begin{array}{l}\text { Setelah data dianalisis lalu dibahas bersama dalam suatu } \\
\text { dianalisis dan ditafsir. } \\
\text { percakapan. }\end{array}$ \\
\hline f. Analisis data & Hasil percakapan yang dibahas bersama untuk ditindaklanjuti. \\
\hline
\end{tabular}

\section{METODE PENELITIAN}

\section{A. Setting Penelitian}

\section{a. Tempat Penelitian}

Lokasi penelitian dalam penelitian tindakan sekolah ini adalah SMPN SMP N 1 Ujung Batu Kecamatan ujung batu yang beralamat di jl Sudirman No 154 .Kecamatan Ujung Kabupaten Rokan Hulu

b. Waktu Penelitian

Penelitian ini dilakukan selama 4 (empat) bulan yaitu dari bulan Juli 2016 s.d. Oktober 2016. Penjelasan secara rinci mengenai waktu pelaksanaan penelitian dapat dilihat pada bagian lampiran 2 penelitian tindakan sekolah ini.

c. Jenis Penelitian

Jenis penelitian ini menggunakan penelitian tindakan sekolah (School Action Research) karena peneliti bertindak secara langsung dalam penelitian, mulai dari awal sampai akhir tindakan. Penelitian adalah kegiatan mencermati suatu obyek, mengguanakan aturan metodologi tertentu untuk memperoleh data atau informasi yang bermanfaat bagi peneliti atau orang orang yang berkepentingan dalam rangka peningkatan kualitas di berbagai bidang. Pada penelitian tindakan sekolah ini yang menjadi fokus penelitian adalah peningkatan kemampuan guru dalam pengelolaan KBM dengan pendekatan kolaboratif di SMP N 1 Ujung Batu Semester 1 Tahun Pelajaran 2016/2017.

\section{B. Metode dan Rancangan Penelitian}

Metode dan rancangan penelitian tindakan sekolah ini dilakukan dengan prosedur penelitian berdasarkan pada prinsip Kemmis dan Taggart (1988:10) yang mencakup kegiatan sebagai berikut : (1) perencanaan (planning), (2) pelaksanaan tindakan (action), 3) observasi (observation), (4) refleksi (reflection) atau evaluasi. Keempat kegiatan ini berlangsung secara berulang dalam bentuk siklus.

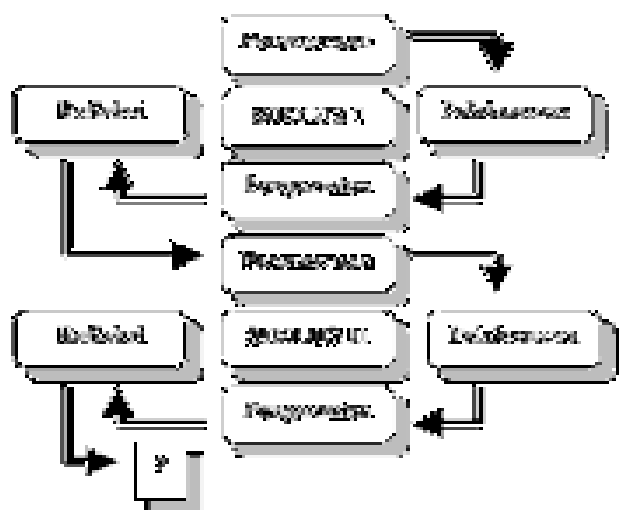

Gambar 3.1 Alur Penelitian Tindakan Sekolah (di modifikasi dari Model Kemmis \& Mc. Taggart

Dari bagan di atas, dapat dijelaskan tiap tahapan-tahapan dalam pelaksanaan penelitian tindakan sekolah sebagaimana diuraikan di bawah ini. 
1. Perencanaan

Rencana penelitian tindakan merupakan tindakan yang tersusun, dan dari segi definisi mengarah pada tindakan. Rencana bersifat fleksibel karena tindakan sosial dalam batas tertentu tidak dapat diramalkan. Rencana disusun berdasarkan hasil pengamatan awal yang reflektif.

2. Tindakan

Tindakan pertama yang dilakukan peneliti adalah menjelaskan cara pengelolaan KBM yang benar sesuai dengan petunjuk teknik dan petunjuk pelaksanaan pengelolaan KBM. Setelah itu para guru diminta menunjukkan perangkat pembelajaranpembelajaran yang dimilikinya. Peneliti kemudian memberikan penilaian terhadap perangkat pembelajaran tersebut, dilanjutkan kegiatan pengamatan pembelajaran di kelas, tanya jawab, diskusi dan membuat kesimpulan akhir kegiatan penelitian.

3. Pengamatan

Pengamatan dilakukan selama tindakan berlangsung menggunakan instrumen antara lain lembar observasi yang dilengkapi dengan catatan lapangan. Hasil observasi digunakan sebagai data yang bersifat kualitatif untuk menilai keberhasilan penelitian secara proses yaitu peningkatan kemampuan kepala sekolah dalam pengelolaan KBM.

4. Refleksi

Refleksi dilakukan dengan cara mengumpulkan semua catatan dan data yang diperlukan selama pembelajaran. Kemudian semua catatan dan data tersebut dianalisis dan hasilnya didiskusikan untuk mengetahui kebenaran data tersebut. Selain itu hasil refleksi tersebut juga unutk mengetahui kekurangan-kekurangan yang masih terjadi selama pembelajaran. Dengan demikian peneliti dan guru kelas menentukan tindakan ulang untuk memperbaiki kekurangan tersebut. Tindakan ulang tersebut berupa siklussiklus lanjutan dari siklus I. Kemudian diadakan refleksi dari data yang diperoleh dari lembar observasi untuk mengetahui peningkatan kemampuan guru dalam pengelolaan $\mathrm{KBM}$ setelah tindakan yang telah dilakukan.

\section{Indikator Keberhasilan}

Indikator keberhasilan dalam pelaksanaan kegiatan penelitian tindakan sekolah ini didasarkan pada hasil observasi yang dilakukan terhadap kelengkapan pembelajaran yang dimiliki oleh masing-masing guru kelas. Guru secara individual dan klasikal dinyatakan telah meningkat kemampuan guru dalam pengelolaan KBMbila minimal memperoleh nilaadalam 7089dan dengan predikat minimal BAIK dan secara klasikal minimal $85 \%$ dari jumlah guru meningkat kemampuannya dalam pengelolaan KBM.

\section{BAB IV \\ HASIL PENELITIAN DAN PEMBAHASAN} A. Hasil Penelitian

\section{1) Siklus I}

Pada tahap tindakan, setelah melaksanakan kegiatan awal penelitian, dan guna meningkatkan pemahaman guru tentang standar pengelolaan PBM, peneliti bersamasama dengan guru-guru melaksanakan diskusi tentang pelaksanaan proses pengelolaan proses belajar mengajar (PBM) yang ideal. Dalam pelaksanaan diskusi tersebut di bahas tentang standar baku proses belajar mengajar (PBM) yang harus dimiliki oleh para guru.

Setelah memberikan penjelasan, para guru diminta berdiskusi tentang dokumen-dokumen yang harus ada dalam pengelolaan proses belajar mengajar (PBM). Guru diminta membuat beberapa contoh tentang dokumendokumen penunjang, misalnya Daftar Hadir Peserta Didik, Struktur Kurikulum yang berlaku, Leger (kumpulan nilai rapor). Kegiatan ini dimaksudkan agar guru yang semakin mengerti dan paham tentang standar pengelolaan proses belajar mengajar (PBM). Hasil pelaksanaan kegiatan pada siklus pertama sebagaimana dijelaskan tabel di bawah ini. 


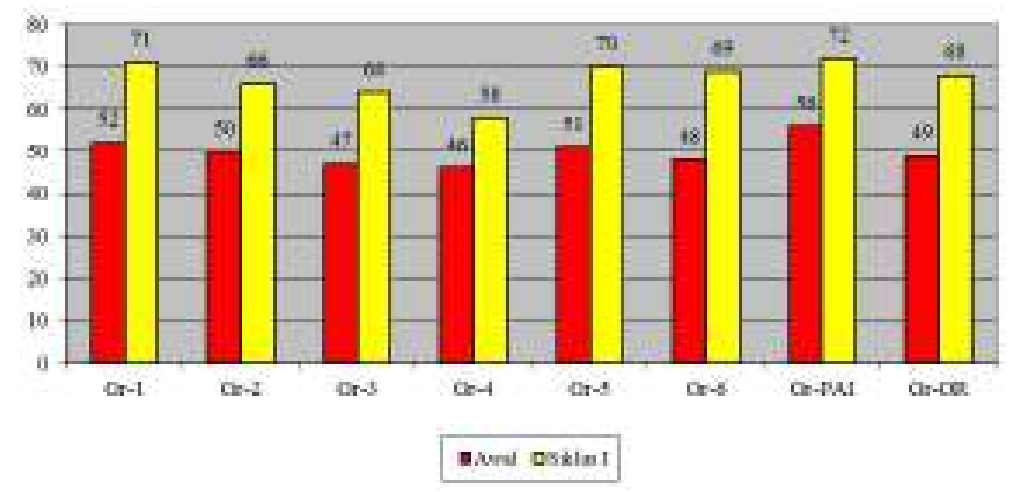

\section{Gambar 4.4 Rekapitulasi Peningkatan Kemampuan Guru dalam Pengelolaan KBM Kondisi Awal dan Siklus Pertama}

\section{2) Siklus II}

Kegiatan penelitian pada siklus II, dimulai dengan kegiatan mengumpulkan guru pada salah satu ruangan yang ada di sekolah, yaitu ruang perpustakaan. Kegiatan ini dilaksanakan setelah jam efektif pembelajaran, tujuannya adalah agar tidak mengganggu kegiatan belajar mengajar siswa. Pada tahap tindakan, peneliti melaksanakan kegiatan diskusi tersebut di bahas tentang standar baku proses belajar mengajar (PBM) yang harus dimiliki oleh para guru, di mana sebelumnya peneliti telah menjelaskan tentang standar pengelolaan proses belajar mengajar (PBM) yang baku dengan menggunakan power point melalui media LCD.

Setelah cukup memberikan penjelasan dengan menggunakan presentasi powerpoint, para guru diminta berdiskusi tentang dokumendokumen yang harus ada dalam pengelolaan proses belajar mengajar (PBM). Guru diminta membuat beberapa contoh tentang dokumendokumen wajib dan penunjang, sementara guru yang lain memperhatikan dan menanyakan apabila ditemukan kesulitan dan ketidakpahaman terhadap jenis dan macam dokumen-dokumen wajib dan penunjang pada perangkat pembelajaran. Kegiatan ini dimaksudkan agar guru yang semakin mengerti dan paham tentang standar pengelolaan proses belajar mengajar (PBM), serta mencari tahu secara mandiri kekurangan-kekurangan apa yang dimiliki oleh masing-masing guru dalam mengelola proses belajar mengajar (PBM) kelasnya masing-masing.

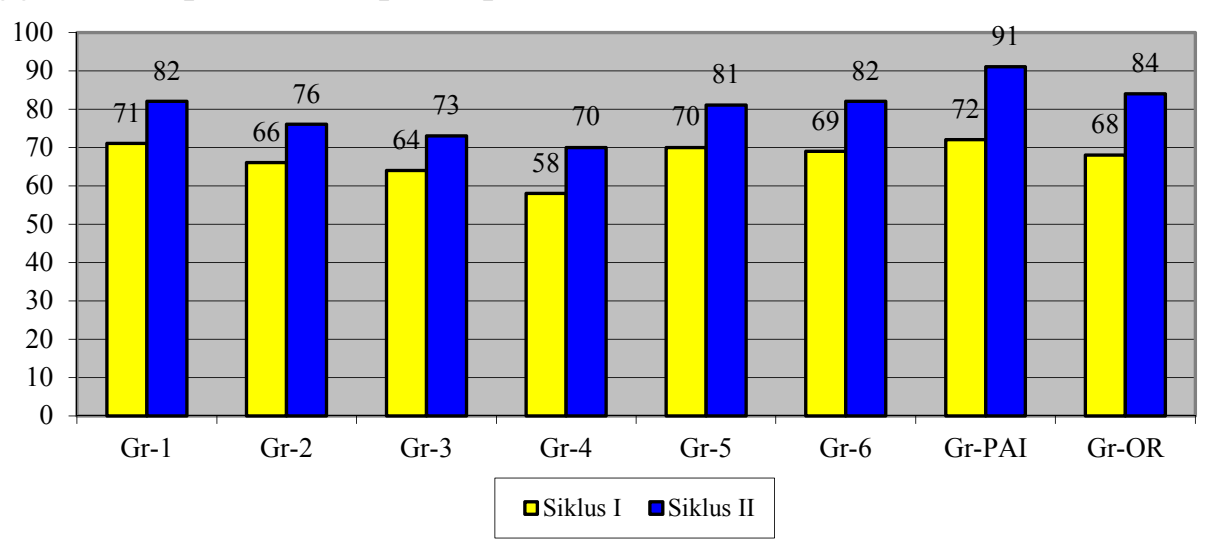

$\begin{array}{ccccc}\text { Gambar } 4.5 & \text { Rekapitulasi Penilaian Peningkatan Kemampuan Guru dalam } \\ \text { Pengelolaan KBM Siklus I dan Siklus II } & & \end{array}$ 
3) Antar Siklus

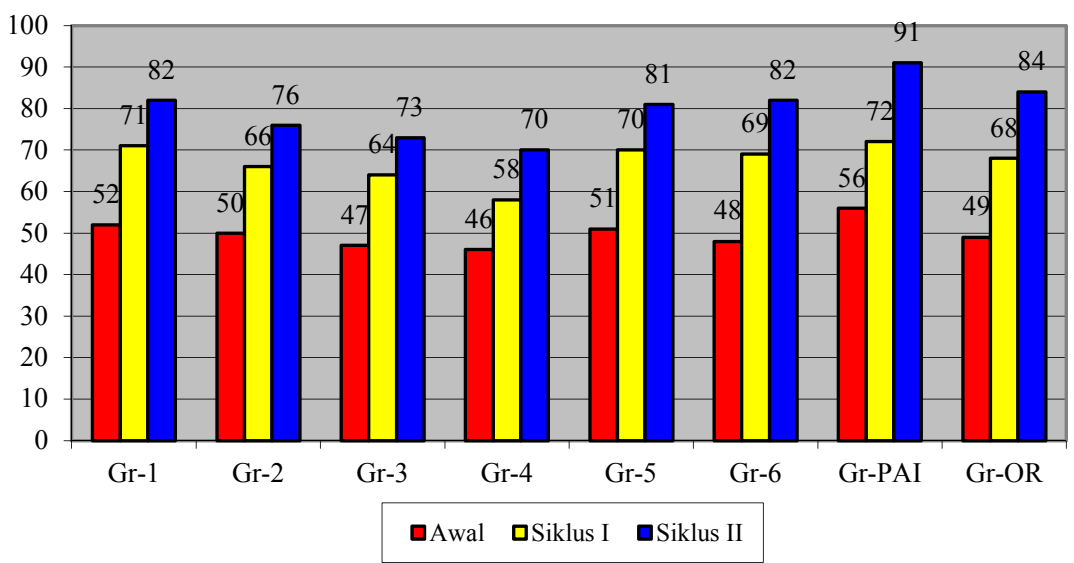

\section{Gambar 4.6 Peningkatan Peningkatan Kemampuan Guru dalam Pengelolaan KBM pada Kondisi Awal, Siklus I, dan Siklus II}

Dari pelaksanaan perbaikan kemampuan guru dalam standar pengelolaan proses belajar mengajar (PBM) dengan kegiatan supervisi akademik dengan pendekatan kolaboratif kelas dapat disimpulkan bahwa kegiatan supervisi akademik dengan pendekatan kolaboratif kelas terbukti mampu meningkatkan kemampuan guru di SMPN 1 Ujungbatu dalam pengelolaan proses belajar mengajar (PBM).

\section{B. Pembahasan}

Hasil penelitian menunjukkan beberapa hal penting mengenai kegiatan supervisi akademik dengan pendekatan kolaboratif yang dilakukan kepala sekolah dalam membina guru di SMPN 1 Ujungbatu khususnya dalam pengelolaan proses belajar mengajar (PBM). Kesimpulan akhir dari pelaksanaan kegiatan supervisi akademik dengan pendekatan kolaboratif terhadap pengelolaan proses belajar mengajar (PBM) membuktikan bahwa pengelolaan proses belajar mengajar (PBM) dalam pendidikan yang tertib dan teratur sangat diperlukan untuk meningkatkan kemampuan pengelolaan pembelajaran bagi pada guru. Peningkatan kemampuan tersebut akan berakibat positif, yaitu makin meningkatnya efisiensi, mutu dan perluasan pada kinerja di dunia pendidikan tersebut. Untuk memperlancar kegiatan di atas agar lebih efektif dan efisien perlu informasi yang memadai. Sistem informasi di dunia pendidikan ini menyangkut dua hal pokok yaitu kegiatan pencatatan data (recording system) dan pelaporan (reporting system).
Hasil pelaksanaan kegiatan penelitian tindakan sekolah dengan menerapkan kegiatan supervisi akademik dengan pendekatan kolaboratif terhadap kemampuan guru dalam mengelola proses belajar mengajar (PBM) di SMPN 1 Ujungbatu menunjukkan adanya peningkatan kemampuan para guru pada setiap siklusnya. Hal tersebut dibuktikan dengan peningkatan hasil penilaian pada setiap siklusnya.

Berdasarkan hasil evaluasi terhadap kemampuan guru dalam mengelola proses belajar mengajar (PBM), maka kepala sekolah perlu refleksi untuk merumuskan tindakan baru atau rencana bimbingan sebagai bentuk tindak lanjutnya. Untuk itu, kepala sekolah harus menyusun beberapa langkah berikut: a) melakukan identifikasi kebutuhan bimbingan kepada guru tentang pengelolaan proses belajar mengajar (PBM), b) melakukan pertemuan individu dengan guru secara informal dalam suasana kemitraan guna melakukan bimbingan kepada guru untuk menyusun berbagai perangkat pembelajaran kelas, c) melakukan kunjungan kelas/ observasi kelas untuk menilai perkembangan kelengkapan guru dalam mengelola proses belajar mengajar (PBM), d) melakukan evaluasi bersama dan refleksi tindak lanjut secara berulang-ulang.

Tindak lanjut terhadap guru yang belum melengkapi perangkat pembelajaran kelas adalah dengan memberikan teguran lisan. Teguran ini diberikan kepala sekolah dalam suasana kemitraan disertai dengan tenggat 
waktu tertentu untuk melengkapi perangkat yang kurang. Kepala sekolah sekaligus memberikan pemahaman akan arti pentingnya perangkat pembelajaran bagi guru khususnya proses belajar mengajar (PBM) yang harus dimiliki masing-masing guru dalam pelaksanaan kegiatan belajar mengajar.

Prosedur pelaksanaan supervisi yang pertama adalah sosialisasi dengan para guru mengenai tujuan dan jadwal supervisi, kemudian kepala sekolah dan para guru yang ditunjuk membantu pelaksanaan supervisi akan melakukan kunjungan kelas sesuai dengan jadwal yang telah disepakati antara supervisor dengan guru yang bersangkutan. Kemudian hasil temuan saat kunjungan kelas akan didiskusikan antara guru dengan kepala sekolah dan selanjunta akan dilakukan tindak lanjut. Teknik kunjungan kelas yang dilakukan kepala sekolah dengan melakukan penilaian kepada guru dengan memberi skor pada setiap proses yang dilakukan oleh guru baik sebelum hingga proses penilaian pembelajaran.

Analisis hasil supervisi akademik dengan pendekatan kolaboratif yang dilakukan kepala sekolah dengan menganalisa secara bersama hasil supervisi akademik yang telah dilaksanakan. Analisis dan evaluasi hasil supervisi akademik dilakukan antara guru yang di supervisi dengan kepala sekolah. Selanjutnya, hasil supervisi akademik terkait masalah yang sifatnya umum, analisis dan evaluasi akan dilakukan melalui rapat antara kepala sekolah dengan para guru. Selanjutnya, pelaksanaan analisis dan evaluasi hasil supervisi akademik di SMPN 1 Ujungbatu dilaksanakan kepala sekolah dengan menyampaikan temuantemuan kepala sekolah sewaktu melakukan observasi kelas dan kunjungan kelas kepada guru yang bersangkutan. Hasil temuan tersebut disampaikan melalui cara individu antara kepala sekolah dengan guru. Selain itu, temuan yang sifatnya umum akan disampaikan melalui rapat antara kepala sekolah dengan guru.

Peningkatan kemampuan guru dalam pengelolaan proses belajar mengajar (PBM), di mana pada kondisi awal tidak ada guru yang mampu menyusun pengelolaan proses belajar mengajar (PBM) dengan baik hal tersebut dibuktikan dengan rendahnya hasil nilai ratarata yang diperoleh guru-guru yaitu 49,50 dan hanya masuk dalam kategori kurang, pada siklus I meningkat cukup signifikan walaupun masih belum ada guru yang dinyatakan mampu mengelola proses belajar mengajar (PBM) dengan baik, dengan peroleh nilai rata-rata secara klasikal sebesar 66,83dan masuk dalam kriteria cukup dan pada siklus terakhir menjadi guru atau $100 \%$, dibuktikan dengan perolehan nilai secara klasikal sebesar 80,17 dalam kriteria nilai baik.

Dari penjelasan tersebut dapat disimpulkan bahwa pada prinsipnya pelaksanaan kegiatan supervisi akademik dengan pendekatan kolaboratif yang dilaksanakan kepala sekolah terbukti dapat meningkatkan kemampuan guru-guru dalam mengelola proses belajar mengajar (PBM) di SMPN I Ujungbatu Kecamatan Ujungbatu Kabupaten Rokan Hulu Semester I Tahun Pelajaran 2016/2017.

\section{KESIMPULAN}

1. Kepala sekolah menerapkan pendekatan kolaboratif. Pendekatan langsung ditunjukkan dengan keaktifan mendekati guru dan melaksanakan rapat guna mengetahui kendala yang dialami guru. Pendekatan tidak langsung ditunjukkan dengan guru yang aktif berkonsultasi dengan kepala sekolah apabila menemukan kendala dalam proses pembelajaran. Kepala sekolah menerapkan teknik kunjungan kelas dan obsevasi kelas untuk mengamati guru dalam proses pembelajaran, pertemuan individu antara kepala sekolah dengan guru. Prinsip supervisi yang diterapkan kepala sekolah yaitu: (1) prinsip kooperatif, yaitu melakukan kerjasama dengan guru untuk saling mengisi dalam rangka memperbaiki kompetensi guru; (2) prinsip berkesinambungan, yaitu melaksanakan supervisi akademik secara teratur setiap tahun; dan (3) prinsip humanis. Dari hasil penelitian mengenai peningkatan kemampuan guru dalam pengelolaan PBM melalui pelaksanaan supervisi akademik dengan pendekatan kolaboratif yang dilakukan oleh kepala sekolah dapat dijelaskan bahwa pelaksanaan supervisi akademik dengan pendekatan kolaboratif ini sudah berjalan dengan baik artinya peran kepala sekolah sebagai supervisor sangat berpengaruh kepada peningkatan kemampuan guru. Pelaksanaan supervisi akademik dengan 
pendekatan kolaboratif ini bersifat intruksional yaitu pelaksanaan supervisi diatur oleh kepala sekolah secara langsung seperti pembuatan jadwal supervisi berdasarkan hasil kesepakatan dengan masing-masing guru, maka guru dapat mengetahui kapan akan dilakukannya kegiatan supervisi. Pelaksanan supervisi akademik dengan pendekatan kolaboratif di SMP N I UJUNGBATU mendapat dukungan penuh dari para guru, karena mereka merasakan manfaat dari diadakannya supervisi akademik dengan pendekatan kolaboratif ini terutama pada aspek kemampuan dalam pengelolaan proses belajar mengajar (PBM).

2. Peningkatan kemampuan guru dalam pengelolaan proses belajar mengajar (PBM), di mana pada kondisi awal tidak ada guru yang mampu menyusun pengelolaan proses belajar mengajar (PBM) dengan baik hal tersebut dibuktikan dengan rendahnya hasil nilai ratarata yang diperoleh guru-guru yaitu 49,50 dan hanya masuk dalam kategori kurang, pada siklus I meningkat cukup signifikan dan terdapat 3 guru atau $37,50 \%$ yang dinyatakan mampu mengelola proses belajar mengajar (PBM) dengan baik, dengan peroleh nilai ratarata secara klasikal sebesar 66,83dan masuk dalam kriteria cukup dan pada siklus terakhir menjadi guru atau $100 \%$, dibuktikan dengan perolehan nilai secara klasikal sebesar 80,17 dalam kriteria nilai baik.

\section{DAFTAR PUSTAKA}

Abdul, Majid. 2012. Pendidikan Karakter. Bandung: Remaja. Rosdakarya

Rohani, Ahmad. 2004. Pengelolaan Pengajaran. Jakarta. PT. Rineka Cipta

Imron, Ali. 2012. "Metode Penelitian Hand Out". Surakarta: Universitas Muhammadiyah Surakarta

Arikunto, Suharsimi., 2009. Prosedur Penelitian Suatu Pendekatan Praktik. Edisi Revisi 6. Jakarta : Rineka Cipta

Arikunto, Suharsimi, 2010. Prosedur Penelitian Suatu Pendekatan Praktek, Jakarta: Penerbit Rineka Cipta

Asf, Jasmani \& Mustafa, S., 2013, Supervisi Pendidikan: Terobosan baru dalam Peningkatan Kinerja Pengawas Sekolah dan Guru, Yogyakarta: Arr - Ruzz Media.
Bafadal, I \& Imron, A. 2004 Manajemen Peningkatan Mutu Berbasis Sekolah. Malang: Kerjasama FIP UM dan DitjenDikdasmen

Davis, B Gordon, et.al 1984, Kerangka Dasar Sistem Informasi Manajemen,. Jakarta Pustaka Bina Presindo.

Departemen Pendidikan Nasional. 2003. Undang-Undang Nomor 20 Tahun 2003, Tentang Sistem Pendidikan Nasional, Jakarta: Depdiknas.

Depdiknas. 2007. Peraturan Menteri Pendidikan Nasional Republik Indonesia, Nomor 13 tahun 2007 tentang Standar Kepala Sekolah/Madrasah.Jakarta: Depdiknas

Flanders, N.A. 1976"Interaction Analysis and Clinical Supervision," Journal of Research and Development in Education, Volume 9 2, Athens, Georgia. Journal of Research and Development in Education. Volume 15, Athen, Georgia

Glickman, 1985 , Intructional Supervision, , New Jersey, Prentice Hall, Inc Englewood Cliftfs

H.B. Sutopo. 2002. Metodologi Penelitian Kualitatif. Surakarta : UNS Press

Krajewski, R.A, Anderson 1982."Clinical Supervision: A Conceptual Framework,"

Mulyasa. 2003. Kurikulum Berbasis Kompetensi. Bandung: Rosda Karya

Oliva, P.F.1984. Supervision for Todays School. New York: Tomas J. Crowell Company.

Purwanto, M. Ngalim. 2004. Administrasi dan Supervisi Pendidikan. Bandung: Remaja Rosdakarya

Purwanto, Ngalim. 2003. Administrasi dan Supervisi Pendidikan. Bandung: Remaja Rodakarya.

Robbins, Stephen P. dan Judge, Timothy A., 2009. Organizational Behavior. 13th Edition. Pearson Education, Inc., Upper Saddle River, New Jersey.

Sahertian, Piet A. 2000. Konsep Dasar dan Teknik Supervisi Pendidikan dalam Rangka Pengembangan SDM. Jakarta: Rineka Cipta.

Sahertian, Piet A. dan Mahateru, F. 2008. Prinsip dan Teknik Supervisi Pendidikan. Surabaya: Usaha Nasional. 
Sanjaya, Wina. 2014. Penelitian Tindakan Kelas. Jakarta: Prenada Media Group.

Subroto Suryo. 2002. Proses Belajar Mengajar di Sekolah. Jakarta. Rineka Cipta.

Sudiarto. 1989. Supervisi Kepala Sekolah. Jakarta: Rineka Cipta.

Suhardjono dan Supardi. 2008. Penelitian Tindakan Kelas.Jakarta : PT. Bumi Aksara.
Tim Penyusun Kamus Pusat Pembinaan dan Pengembangan Bahasa. 1989. Kamus Besar Bahasa Indonesia. Jakarta : Balai Pustaka

Tisnowati Tamat dan Moekarto Mirman. 2005. Pendidikan Jasmani dan Kesehatan. Jakarta: Universitas Terbuka.

Wiles, Kimball, John T Lovell, 1975. Supervision for Better Schools. New Jersey: 